International Journal of Engineering \& Technology, $7(2.29)(2018)$ 1015-1018
International Journal of Engineering \& Technology
SPC
Website: www.sciencepubco.com/index.php/IJET
Research paper

\title{
Reconstruction of Zakah Governance in Indonesia (Review on the No. 23 Year 2011)
}

\author{
Cahyo Budi Santoso ${ }^{1 *}$, Mohammad Nizarul Alim² Slamet Riyadi $^{3}$ \\ ${ }^{1}$ Universitas Riau Kepulauan Batam, Indonesia \\ ${ }^{2}$ Universitas Trunojoyo Madura, Indonesia \\ ${ }^{3}$ Universitas 17 Agustus 1945 Surabaya, Indonesia \\ *Corresponding Author E-Mail: Cafana07@gmail.com
}

\begin{abstract}
The issuance of Law Number 23 Year 2011 on the Management of Zakat changed the paradigm of zakat management in Indonesia. The purpose of this study is to assess the governance of zakat based on zakat regulation. The content zalcat content analysis approach shows that BAZNAS has two major roles, namely the coordinator and operator. Supervision is an important element in zalcat governance, currently the state plays a role in supervising the aspects of sharia only [this is done by the Ministry of Religious Affairs] while the supervision on financial management has not been done by the Financial Services Authority [OJK]. Supervision over zakat governance by OJK should be a necessity considering the zakat fund managed by amil zakat nationally more than 3 trillion Rupiah.
\end{abstract}

Keywords: Zakat; Organization; Management of Zakat; Governance

\section{Introduction}

Law No. 23 of 2011 on Management of Zakat has changed the paradigm of zakat implementation in Indonesia. One of the most important things in this Act is the existence of the regulation on the authority of National Amil Zakat Agency [BAZNAS] as the coordinator of the management of national zakat [article 6]. This law also gives the meaning that zakat in Indonesia is not merely ubudiyah implementation which is only religious ritual, more than that the implementation of zakat is part of positive law product that should be able to be controlled through state apparatus [1].

Legislation on zalcat management also changed the paradigm of zalcat governance in the form of a committee into an institutional governance. Zakat, which was originally managed with human resources as it is, now uses standard qualifications as in a company. Similarly, in terms of management of zakat distribution, also experienced the development. zakat can be utilized for productive purposes to deal with the poor and improve the quality of society so that zakat can be enjoyed not only in the moment of Ramadan but also can be benefited throughout the month and throughout the year [2].

In addition to some of the advantages of the enactment of the Law on Zakat Management as described above there are also several factors that are also considered as weaknesses. The law has not fully realized the actual zalcat governance, for example the absence of sanctions for muzaki who neglected the obligation of zakat [3] or the form of punishment against the delay of paying zakat [1]. Another thing that should also be important in zakat legislation is the organizational control system mechanism. Implementation of zakat as according to the law is a guarantor of religious trust alone. This is as set forth in Article 8 of Law Number 23 Year 2011 regarding Zakat Management.

The law on zakat management as reinforced by Government Regulation No. 14 of 2014 has placed BAZNAS as the official body appointed by the government to manage zakat significantly. At the same time the existence of BAZNAS will also weaken the position of Lembaga Amil Zakat [LAZ] which has been the pioneer in zakat management initiated by the community. This will certainly break the zakat manager structure, which should be one roof. Whereas the purpose of the birth of zakat legislation is almost certainly to maintain order, awareness and maximal utilization of zakat, not inhibit its implementation

Zakat funds have the potential to be developed economically. In the last decade, zakat has developed rapidly when viewed from its growth. However, the growth of zakat is still very far away with the true potential of zakat. According to some studies, zakat potential in Indonesia varies between $\mathrm{Rp} 12.7$ trillion and $\mathrm{Rp} 286$ trillion [Outlook Zakat Indonesia 2017]. This variation is more due to different approaches in calculating the potential of zakat. This potential even reaches $16 \%$ of the state budget of the Republic of Indonesia in 2017 [amounting to Rp 1,750.3 trillion]. Zakah receipts from 2002 to 2015 continue to increase. The average revenue growth reaches $39 \%$ per year. Despite the growth of zakat fund receipts, but the achievement is still far from expectations. In 2015 zakat funds collected amounting to $\mathrm{Rp} 3.7$ trillion or just $1.3 \%$ of its potential of $\operatorname{Rp} 286$ trillion.

The low performance of zakat fund is still a lot of weaknesses in Zakat Management Act, the writer feel the need to conduct study to understand the benefit of zakat especially related to zakat governance in review of Law no. 23 year 2011.

\section{Literature Review}

\subsection{Preview Research}

The results of research on accountability and transparency by [4] obtained the result that accountability and transparency have a positive effect simultaneously on performance-based budget. Par- 
tially, transparency has a positive effect on performance-based budgets. This study also shows that respondents have a perception that is more transparent than accountability.

Results of research conducted by Wardayati [5] show that the implementation of shariah governance includes six indicators, namely transparency, accountability, responsibility, independence, justice, and shariah compliance. Shariah compliance is a dominant indicator of Islamic governance, while accountability and fairness are weak indicators for explaining shariah governance. Implementation of shariah governance has a significant influence on the reputation and trust of customers.

Research by Boy and Siringoringo [6] suggests that accountability and transparency in fund management have a positive effect on participation.

Research conducted by Hamid and Azmi [7] states that the principle of Transparency, Accountability and Independence have a positive and significant impact on Employee Performance and only the principle of Responsibility and Justice impact on the Performance of the Organization. Employee performance serves as a fully mediator between the principles of Transparency and Accountability with Organizational Performance and acts as a partially mediator between these relationships.

Research conducted by Chapra, Khan et al.[8] on the implementation of Corporate Governance conducted by IRTI in sharia banking in various countries shows the implementation of Good Corporate Governance has not been implemented properly. Implementation of Good Corporate Governance is proven in research in some Islamic financial institutions in the Muslim world can increase public trust to Islamic banks. Failure in the implementation of sharia principles will make the customer move to another bank by $85 \%$.

\subsection{The Legal Basis of Zakat}

According to the language [lughat], zakat means: to grow; developing; fertility or increase [HR At-Tirmizi]. or it could mean cleaning or purifying QS. At-Taubha: 103, "Take zakat from some of their possessions, with the charity you clean and purify them". That is, the zakat cleans them of the miserliness and excessive love of the treasure, and nourishes such good qualities as compassion, cares for others and develops their wealth [9]. Another foundation of zakat law lies in Surat At Taubah verse 18 which means "Truly, the enlightenment of Allah's mosques is only those who believe in Allah and the Last Day, establish prayers, pay Zakat and not fear anyone but Allah". Zakat is a certain amount of property that Allah requires and is handed over to the righteous [10] While Hafidhuddin [11] states that zakat is a property that has met certain conditions issued by the owner to the person entitled to receive it.

According to Islamic law [syara '], zakat is the name for a certain taking of certain property, according to certain traits and to be given to a particular group [Al Mawardi in the book of Al Hawiy] The term zakat is also equated with shadaqah and infaq. "Sedekah will not reduce property" [HR Tirmizi], and some fiqh scholars say that sadaqah is obliged to be called zakat, while sadaqah sunnah is called infaq. Some others say infaq must be called zakat, while infaq sunnah is called shadaqah. Based on the above understanding can be deduced that zakat is a liability for certain people on certain property, managed to be given to certain people.

The purpose of zakat is to achieve economic justice [12]. Zakat is a simple transfer from the part that has the right to receive. The purpose of zakat is also to improve the welfare and poverty reduction [article 3 of Act No.23 of 2011], with the existence of zakat will uplift the poor and help him out of the difficulties of life and suffering, protecting people from the danger of poverty and poverty [13].

The implementation of zakat management is based on the word of Allah in QS Al-Taubah verse 60 which means "The zakat is only for the poor, the poor, the amil zakat, which is softened their hearts [converts], to liberate the slave, to free the debtors, for those who are in the way of Allah and for those who are on the way as a duty from God. Allah is the Knower, the Wise". Based on that verse, it can be seen that the management of zakat is not solely done individually, from muzakki submitted directly to mustahiq, but implemented by a special agency handling zakat, which fulfill certain requirements called zakat amil. Amil zakat is the task to socialize to the community, collect, collect, and distribute zakat properly and correctly. The management of zakat by amil zakat has several advantages, to ensure the certainty and discipline of paying zakat, to keep the low self-esteem of the mustahiq zakat when facing directly receive zakat from zakat obligation [muzakki], to achieve efficiency and effectiveness as well as proper target in the use of zakat price according to priority scale that exist somewhere.

Organizational management of zakat has an important role in the management of zakat, receive zakat from muzaki and channel it to mustahiq. One of the great ideas of managing zakat management as stipulated in Law No. 23 of 2011 and animating the whole article is integrated management. The state in this case BAZNAS is authorized to manage zakat [14]. The word "integrated" becomes the principle that underlies the zakat management activities in our country, whether by the National Amil Zakat Bodies [BAZNAS] at all levels and the Amil Zakat Institution that gets legality in accordance with the provisions of the legislation. The role of zakat managers in overcoming the widening inequality, demanding to be an organization must implement a good accountability system. Thus, governance becomes an important factor in the optimization of resources owned by zakat management organizations, so as to be able to manage zakat in accordance with Islamic sharia [Compliance fully with islamic law and principle], assurance of comfort [Assurance], level of trust or trust [Reliability] concrete evidence [Tangibles], empathy [Empathy], and manager responses to customer service complaints [Responsiveness] [15]. Thus, to meet a good governance system, the organizers of zakat managers must meet the standard of good governance.

\subsection{Shariah Governance}

The term shariah governance in developed from the concept of good corporate governance and shariah compliance. According to Algoud and Lewis [16] Good Coporate Governance [GCG] is the arrangement and institutional relationship that directs and controls a company. The provisions of article 1 point 6 of Bank Indonesia Regulation Number 8/4 / PBI / 2006 concerning the Implementation of Good Corporate Governance for Commercial Banks, namely good corporate governance is a bank governance that applies the principles of transparency, accountability, responsibility, independency, and fairness. Devano and Rahayu in Wardawati [2011] stated that the Forum for Corporate Governance in Indonesia [FCGI] defines corporate governance as "a set of rules establishing relationships among stakeholders, managers, creditors, government, employees and other internal and external stakeholders".

Damanhuri [17] states that the characteristics of "good governance" are: transparency, public accountability, rule of law, community participation, efficiency and effectiveness, stakeholder care, equity, consensus-oriented and strategic vision. While it is stated in general there are some characteristics and values inherent in governance practices. First, good governance practices should give space to non-governmental actors to play an optimal role in governmental activities to allow for synergies between government actors and agencies with non-governmental organizations such as civil society and market mechanisms. Secondly, good governance practices contain values that enable governments to more effectively work to achieve common prosperity. Values such as efficiency, fairness, and responsiveness are of great value. Third, good governance practice is a clean government practice and free from corrupt practices and oriented to the public interest. Therefore, the practice of government is considered good if able to realize transparency, law enforcement and public accountability. In the guidelines of good corporate governance of Indonesian banking issued by KNKCG there are 5 principles in the implemen- 
tation of good corporate governance, namely: [1] transparency; [2] accountability; [3] responsibility; [4] independency and [4] fairness.

Accountability is one of the main principles of organizational governance that implies the realization of a person's or organizational unit's obligations to account for the management and control of resources and the implementation of the policies entrusted to it in the context of achieving the objectives established through the media of periodic accountability [18-21].

The management of zakat funds in order to empower the people's economy is one of the contemporary results of contemporary ijtihad. Ijtihad in the field of zakat, has been implemented in Indonesia, both individually and in the constitution. The emergence of such a result of ijtihad is due to the reality of Muslims who always slump at the bottom layer of economic activity; production, distribution and consumption, both in global and local discourse. According to the great purpose of zakat management as mandated by Law No.23 / 2011, improve the effectiveness and efficiency of services in the management of zakat; and increase awareness of the benefits of zakat to realize the welfare of society and poverty alleviation, then there are some things that can be reviewed again to be reinforced in the provisions contained in the law of zakat so that the goal can be realized effectively as aspired.

\section{Methodology/Materials}

The research method used by researchers is qualitative research By using approach which appropriate with this research is approach of content analysis. Content analysis is simply defined as a method for mengunpulkan and analyze the content of a "text". Text can be words, meanings of images, symbols, ideas, themes and various forms of messages that can be communicated. Conten analysis seeks to understand data not as a collection of physical events, but as a symbolic phenomenon to express the meaning sometimes in a text, and gain an understanding of the message it represents [22].

\section{Results and Findings}

Zakat is worship mahdah with a special position in Islam, that is according to Quran QS. At Taubah verse 103: "khuz min amwalihim", then the zakat collecting authority is the government. Thus, ignoring the role of the state in the management of zakat contradicts the Qur'an. The birth of the Zakat Management Act implies that the management of zakat in Indonesia enters the institutionalization stage of management within the formal territory of the state, although it is still very limited. The State assumes the role of responsibility in its management through BAZNAS [article 6].

In Chapter II Article 5 paragraph [3] of Law Number 23 Year 2011 on the Management of Zakat affirmed that; BAZNAZ as referred to in paragraph [1] is a non-structural government institution which is independent and responsible to the President through the Minister. Referring to the above provisions, there is an unpreparedness of the government to integrate regulations and bureaucratic system among institutions or entities that should be in synergy with BAZNAS [1]. The government only legalizes zakat without standard procedure so that zakat and its governing body that BAZNAS operate separately with other institutions. The system of accountability also looks very simple without any auditor An institution that manages funds worth billions or even in trillions of numbers on a national scale is a gap for non-conformities. Thus, the lack of legislation is perceived as more complete than all the roles under BAZNAS [regulator, motivator, facilitator and coordinator] as a representation of the government's role. In this context, a question arises who is authorized to audit the LAZ institution, and who is authorized to audit BAZNAS. It can be asserted that zakat is not merely philanthropic affairs but also authoritativeimpulsive, therefore zakat management by zakat management institutions must have formal legal force. The function of the formal law is certainly not only as a legal umbrella but also as a con- tribution to the rule of law and the system of governance of zakat implementation.

There are two major roles of BAZNAS in zakat management, namely as coordinator and operator. As a coordinator role in coordinating the management of zakat by the Provincial BAZNAS, BAZNAS Kab / kota including the Institute of Amil Zakat [LAZ]. This real role can be seen from the coordination meetings held annually by BAZNAS, making the data centralization system to create operational technical rules, including the provision of new LAZ formation as well as representatives. As the operator plays an active role in collecting zakat funds at government agencies according to level, but free in terms of channeling. Meanwhile, LAZ collects funds from all walks of life outside government agencies. As the operator that manages the ummat funds, BAZNAS needs to account for the performance of both fund management and compliance with sharia. Good governance should also reflect good oversight. According to Sujamto [23], supervision is a business or activity to know and assess the actual reality of the implementation of tasks or activities, accordingly or not properly.

As the purpose of establishing the Financial Services Authority $[\mathrm{OJK}]$ is to ensure that all financial services activities within the financial services sector can be organized on a regular, fair, transparent and accountable basis and can achieve a sustainable and stable financial system. The areas under OJK supervision include the banking industry, insurance, pension funds, capital markets, finance companies, and other bodies that manage public funds.

To ensure the purpose of establishment of the OJK, the OJK must be part of the system of state affairs organizers that are well integrated with other state and government institutions. In addition, in order for OJK to perform its functions effectively, OJK must have independence in carrying out its functions in order to be protected from various interests. This independence is manifested in two ways. Firstly, OJK institutionally is not under any other authority in the system of the Government of the Republic of Indonesia, and secondly, the individual who leads the OJK must have the assurance of his position in the form of an irreplaceable term of office in so far as to carry out the duties properly and not to engage in crime [1].

Currently being carried out on zalcat organizations is oversight of the performance of the National Amil Zakat Bodies conducted internally by the Supervisory Commission at all levels, and externally by the Government and the community. Law No. 23 of 2011 on the Management of Zakat mandates the need for supervision. Supervision is done by two parties, namely the government and the community. The government through the Minister of Religious Affairs by supervising BAZNAS, Provincial BAZNAS, District / City BAZNAS, and LAZ. Supervision under OJK authority has not been seen in the Zakat Management Act [3].

\section{Conclusion}

Regulation is one of the most important variables in zakat development. Therefore, all elements including scholars and academics and even politicians, must always encourage the creation of proregulation on the growth of zakat nationally.

One of the elements of good governance is the existence of a good supervisory system. BAZNAS as national zakat coordinator should supervise not only on sharia aspect [done by Ministry of Religious Affairs of Indonesia] but also on financial accountability aspect [done by OJK]. This study uses content analysis techniques, hope can be followed up with other analysis techniques to obtain more comprehensive results.

\section{References}

[1] Mufidah. Institutional Hierarchy System of Zakat Management Agency In Indonesia [Review of Implementation of Law Number 23 Year 2011]. Journal of Law Cita. 2014;4[2]:323-44.

[2] Alim MN. Utilization and Accounting of Zakat for Productive Purposes in Indonesia: A Review. Procedia-Social and Behavioral Sciences. 2015;211:232-6. 
[3] Hakim BR. Analisis Terhadap Undang-undang Nomor 23 Tahun 2011 Tentang Pengelolaan Zakat [Perspektif Hukum Islam]. Syariah Jurnal Hukum dan Pemikiran. 2016;15[2].

[4] Adiwirya MF, Sudana IP. Akuntabilitas, Transparansi, dan Anggaran Berbasis Kinerja Pada Satuan Kerja Perangkat Daerah Kota Denpasar. E-Jurnal Akuntansi. 2015:611-28.

[5] Wardayati SM. Implikasi Shariah Governance terhadap Reputasi dan Kepercayaan Bank Syariah. Walisongo: Jurnal Penelitian Sosial Keagamaan. 2011;19[1]:1-24.

[6] Boy D, Siringoringo H. Analisis pengaruh akuntabilitas dan transparansi pengelolaan anggaran pendapatan dan belanja sekolah [APBS] terhadap partisipasi orang tua murid. Jurnal Ilmiah Ekonomi Bisnis. 2011;14[2].

[7] Hamid MA, Azmi SM. The Performance Of Banking During 2000 2009: Bank Islam Malaysia Berhad And Conventional Banking In Malaysia. International Journal of Economics and Management Sciences. 2011;1[1]:09-19.

[8] Chapra MU, Khan T, formation Iidred. Regulation and supervision of Islamic banks: Islamic Research and Training Institute; 2000.

[9] Bakry H. Islamic Guidelines in Indonesia. Jakarta: UI Press; 1988.

[10] Qardhawi Y. Teologi Kemiskinan: Doktrin Dasar dan Solusi Islam atas Problem Kemiskinan. Yogyakarta: Mitra Pustaka. 2002.

[11] Hafidhuddin D. Zakat dalam perekonomian modern: Gema Insani 2002.

[12]Zakiyuddin. The Concept of Economic Justice In Islam. Yogyakarta: UIN Sunan Kalijaga2006.

[13] Ramulyo HI. Kumpulan Soal ujian Negara Cicilan Hukum Islam. Penerbit Sinar Grafika: Jakarta. 2000:106.

[14] Aziz M. Zakat Regulation In Indonesia; Efforts Toward Professional Zakah Management. AL HIKMAH. Jurnal Studi Keislaman. 2014;4[1].

[15] Abdulqawi O, Lynn O. The Multi Dimensionality of CARTER Model to Measure Customer Service Quality in Islamic Banking Industry: A Study in Kuwait Finance House. International Journal of Islamic Services. 2002;3[4]:1-12.

[16] Algoud LM, Lewis MK. Perbankan Syariah, terjemahan. Serambi, Jakarta. 2001

[17] Damanhuri DS. Negara, Civil Society, dan Pasar dalam Kemelut Globalisasi. Lembaga Penerbit FE-UI Jakarta; 2009.

[18] Saragi FK. National Accountability Guidelines. Jakarta : State Administration Agency. Jakarta2012.

[19]Alamer ARA, Salamon HB, Qureshi MI, Rasli AM. A New Business Process and Outcome Oriented Corporate Social Responsibility Index for Islamic Banking. International Journal of Economics and Financial Issues. 2015;5.

[20] Alamer ARA, Salamon HB, Qureshi MI, Rasli AM. How do We Measure Corporate Social Responsibility of Islamic Banks through their Business Processes and Oriented Outcomes? International Journal of Economics and Financial Issues. 2015;5.

[21]Alamer ARA, Salamon HB, Qureshi MI, Rasli AM. CSR's measuring corporate social responsibility practice in Islamic banking: A review. International Journal of Economics and Financial Issues. 2015;5[1S]

[22]Bell P. Content analysis of visual images. Handbook of visual analysis. 2001;13.

[23] Sujamto BPdBP. Ghalia Indonesia. Jakarta,[cet kedua]. 1986. 